\title{
An unusual form of renal disease associated with gout and hypertension
}

\author{
W. VAN GOOR ${ }^{1}$, C. J. KOOIKER ${ }^{2}$, AND E. J. DORHOUT MEES \\ From the University Hospital and the Pathological Institute, University of Utrecht, Utrecht, \\ The Netherlands
}

SYNOPSIS A family is described many of whose members suffered from renal insufficiency, hyper tension, gout, and hyperuricaemia in conjunction. Adequate information was obtained on 72 subjects from five generations. In 17, one or more of the above mentioned abnormalities was or had been present. The hereditary distribution suggested an autosomal dominant disease entity.

The renal disease was characterized by an early loss of urinary concentrating power, minima proteinuria, and death at a relatively early age dominating the clinical picture.

The histological picture in three biopsies and one necropsy showed predominant tubular atrophy and interstitial fibrosis, with striking tubular basement membrane thickening.

It is suggested that these patients suffered from a hereditary degenerative renal disease. The question whether hyperuricaemia was primary or secondary in these cases is discussed.

Most authorities (Talbott and Terplan, 1969; Stanbury, Wijngaarden, and Fredrickson, 1966) consider gout to be a primary inherited metabolic disorder. It is often associated with an ill defined form of 'degenerative' renal disease, probably secondary in nature, which is slowly progressive (Gutman and Yü, 1957) and may eventually lead to death through renal failure. Opinions on the frequency of this event differ from 10 to $25 \%$ in various reports (Gonick, Rubini, Gleason, and Sommers, 1965; Heptinstall, 1966; Talbott and Terplan, 1960). On the other hand, any type of renal failure will eventually lead to hyperuricaemia but clinical gout secondary to renal disease is rare (Merrill, 1955; Richet, Mignon, and Ardaillou, 1965; Heptinstall, 1966).

In this paper a family is described in which fatal renal disease, and in many cases hypertension, occurred, together with hyperuricaemia and gout. The particular gravity of the renal disease, overshadowing the manifestations of gout as well as the anatomical lesion, distinguished these patients from those with classical 'gouty nephropathy'. The possibility that they represent a hitherto not clearly defined disease entity should therefore be considered.

Received for publication 14 July 1970.

'Present address: Deaconess Hospital, Haarlem, The Netherlands. 'Pathological Institute, Pasteurstraat, Utrecht, The Netherlands.

\section{Methods}

Creatinine concentrations were measured by the AutoAnalyzer technique. Creatinine clearances were $\overrightarrow{\vec{b}}$ calculated from 24-hour urine specimens. Uric acidB in blood and urine was determined by the method of Caraway (1955). Concentration tests were performe $\bar{d}$. by 20 hours of fluid restriction.

\section{The Family}

Five generations were investigated, consisting of 7 응 direct descendants. Twenty-five relatives by marriage were also studied. Of these 97 persons, 67 were examined personally by one of us; 24 of the remainings 29 were dead at the time of the study but adequate information on the illness and cause of death wass collected by interviewing acquaintances and familyn doctors as well as from medical records. Five childrem were not examined. Among the relatives by marriage $\omega_{\sigma}^{\omega}$ three probably had been suffering from hypertension, none showed signs of renal disease, gout, or 'related? illnesses (diabetes, obesity, arteriosclerosis). Con sanguinity was not found to be present or likely to be present in any of the marriages.

Figure 1 shows that in the grandfather and his direc descendants hyperuricaemia, gout, renal disease, and hypertension frequently occurred simultaneously? Typical gouty arthritis, renal failure, hypertension? 


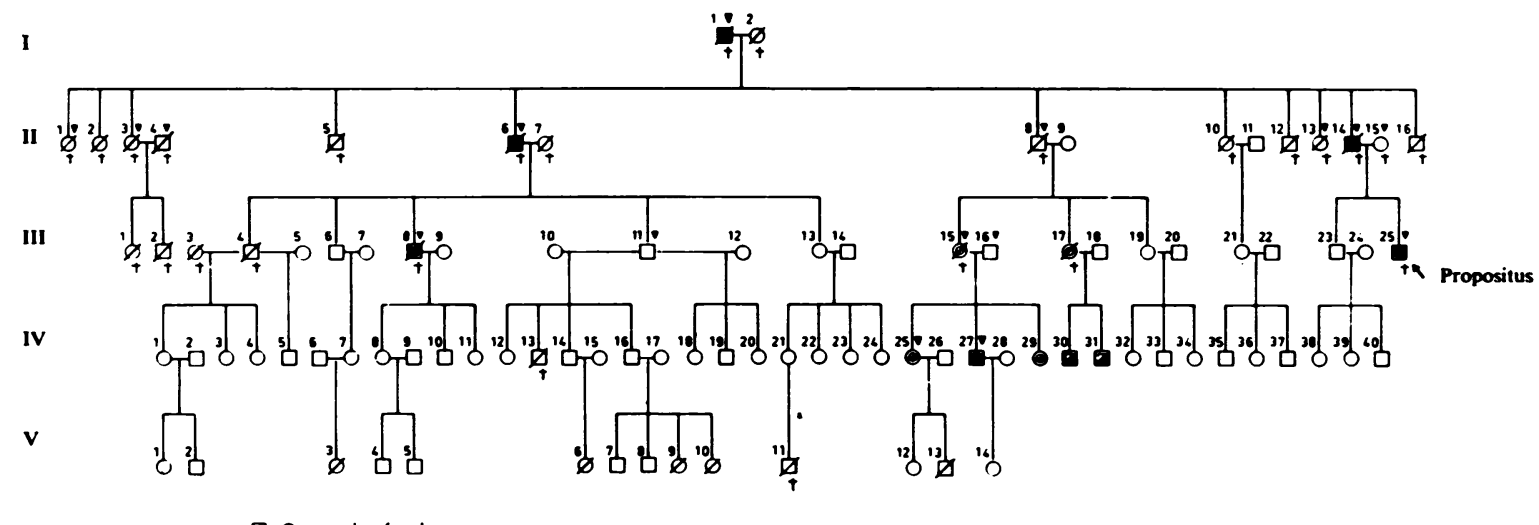

口 O male temale

$\square \varnothing$ not examined

- O ipperurcema

- gout

- 9 renal disezse

¿ ó mpertension

무 dead

Fig. 1. Pedigree of the family.

No. of Cases with

\begin{tabular}{llll}
\hline Hypertension & $\begin{array}{l}\text { Hypertension, } \\
\text { Renal Insuf: } \\
\text { ficiency, and } \\
\text { Hyperuricaemia }\end{array}$ & $\begin{array}{l}\text { Hypertension, } \\
\text { Renal Insuf- } \\
\text { fiency, Clinical }\end{array}$ & $\begin{array}{l}\text { Renal Insufiency and } \\
\text { Gound } \\
\text { Hyperuricaemia }\end{array}$ \\
\hline 1 & 1 & 2 & 3
\end{tabular}

Table I Distribution of abnormalities found in seven of 47 persons examined

\begin{tabular}{llll}
\hline No. of Cases with & $\begin{array}{l}\text { Renal } \\
\text { Insufficiency }\end{array}$ & $\begin{array}{l}\text { Hypertension } \\
\text { and Renal } \\
\text { Insufficiency }\end{array}$ & $\begin{array}{l}\text { Hypertension, } \\
\text { Renal Insuf- } \\
\text { ficiency, and Gout }\end{array}$ \\
\hline 4 & 1 & 1 & 4
\end{tabular}

Table II Distribution of abnormalities in 10 out of 20 deceased patients

and hyperuricaemia were found in various combinations in seven of the 47 subjects examined (Table I). Of the 20 members of the family who were dead at the time of the study, 10 had been suffering from either podagra, renal insufficiency, or hypertension (Table II).

\section{CLINICAL PICTURE}

Of the 20 deceased members of the family, five had died from uraemia between $\mathbf{4 0}$ and 50 years of age. Four had died from a stroke between 38 and 54 years of age, three others probably suffered from coronary atherosclerosis, death being due to a 'heart attack' between 35 and 69 years of age. Blood uric acid levels in these patients were unknown and there was no certainty as to whether renal impairment had led to symptoms. Four of these people suffered from clinical gout.

In six of the living family members we found varying degrees of abnormality (Table III). The first patient we investigated was a man of 37 years (propositus, III, 25) who had suffered a single attack of podagra two years before. His mentioning a 'family ailment' initiated the present investigation. He presented with incipient renal failure and complaints of general discomfort and 'convulsions'. At that time a renal biopsy was performed. He was followed up until his death four years later. With conservative treatment, including uricosurics, he remained well for three years without attacks of gout. During the last months of his life he suffered from severe sciatic pains and pain in the shoulders caused by uraemic osteodystrophy.

In five young relatives hyperuricaemia was found; only one of them (III, 27) had suffered from attacks of podagra since the age of 20 . All had a markedly diminished renal concentrating power. Three had some degree of hypertension and decreased creatinine clearances. None of them secreted more than normal amounts of uric acid (Table III). These five patients were treated with probenecid or sulphinpyrazone for four years and more, so reducing blood uric acid to near normal levels. This prevented further attacks of gout but caused no improvement in the renal function.

RENAL FUNCTION

It was not possible at the time of the study to perform detailed renal function analyses. The available data 
W. van Goor, C. J. Kooiker, and E. J. Dorhout Mee $\frac{\varrho}{\overline{\frac{S}{5}}}$

\begin{tabular}{|c|c|c|c|c|c|c|c|c|c|c|}
\hline \multirow{2}{*}{$\begin{array}{l}\text { Place in } \\
\text { Family }\end{array}$} & \multirow[t]{2}{*}{ Sex } & \multirow{2}{*}{$\begin{array}{l}\text { Age } \\
(y r)\end{array}$} & \multirow{2}{*}{$\begin{array}{l}\text { Blood } \\
\text { Pressure } \\
(\mathrm{mmHg})\end{array}$} & \multicolumn{5}{|l|}{ Urine } & \multirow[t]{2}{*}{ Gout } & \multirow{2}{*}{$\begin{array}{l}\text { Biopsy } \\
\text { Performed }\end{array}$} \\
\hline & & & & $\begin{array}{l}\text { Maximum } \\
\text { Specific } \\
\text { Gravity }\end{array}$ & Proteinuria & $\begin{array}{l}\text { Creatinine } \\
\text { Clearance } \\
\text { (ml/min) }\end{array}$ & $\begin{array}{l}\text { Serum } \\
\text { Acid }\end{array}$ & $\begin{array}{l}\text { Uric Acid } \\
\text { Excretion } \\
\text { (mg/24 hour) }\end{array}$ & & \\
\hline III, 25 & $\mathbf{M}$ & 37 & $180 / 115$ & 1014 & Trace & 20 & $13 \cdot 5$ & 200 & $\perp$ & - \\
\hline IV, 25 & F & 30 & $170 / 110$ & 1009 & - & 54 & $10 \cdot 0$ & 246 & - & + \\
\hline IV, 27 & $\mathbf{M}$ & 28 & $155 / 110$ & 1015 & - & 41 & $10 \cdot 5$ & 274 & + & - \\
\hline IV, 29 & $\mathbf{F}$ & 16 & $140 / 85$ & 1008 & - & 67 & 10.5 & 475 & - & $\div$ \\
\hline IV, 30 & $\mathbf{M}$ & 19 & $120 / 80$ & 1001 & - & 70 & $8 \cdot 1$ & 436 & - & - \\
\hline IV, 31 & $\mathbf{M}$ & 15 & $120 / 80$ & 1014 & - & 99 & $6 \cdot 6$ & 547 & - & - \\
\hline
\end{tabular}

Table III Details for six subjects with hyperuricaemia

on six of the family members with hyperuricaemia are given in Table III. All showed a marked inability to concentrate urine in the presence of slight to moderate depression of the creatinine clearance, except in the youngest subject, in whom the latter was within the normal range. The 24-hour urinary excretion of uric acid was diminished in patients with the lowest glomerular filtration rate and within normal limits in the three least affected subjects. Significant proteinuria and abnormalities of sedimentation were absent at repeated examinations.

MORBID ANATOMY

Renal biopsies were performed in four of the patients. The biopsies from the three patients (IV, 25, IV, 27, IV, 29) who had only slight renal functional impairment showed a largely identical picture. The biopsy material consisted mainly of medullary tissue and contained only a small number of glomeruli. In two biopsies (IV, 25 and IV, 29) some glomeruli were hyalinized; the other biopsies showed either no significant glomerular lesions or a doubtful increase in mesangial fibres (IV, 27). In IV, 27 and IV, 29 capsular basement membranes were thickened and there was tubular atrophy; in IV, 25 many tubules were dilated. In all three biopsies there were tubules containing protein casts, and brown, granular intracellular pigment, presumably lipofuchsin. Some tubules were surrounded by a thickened basement membrane (Fig. 2). Interstitial infiltrates of plasma cells and lymphocytes were present to a varying extent in all biopsies. No uric acid deposits were observed.

In the renal biopsy from the propositus (III, 25), taken four years before his death at a time when renal function was already severely impaired, most of the Malpighian bodies were hyalinized with the appearance of ischaemic atrophy. In the less affected glomeruli the lobular stalks were broadened by PAS-positive fibrillar material. No nodularglomerulosclerotic lesions or lipohyaline deposits were found. Many tubules were atrophic, their epithelial cells containing brown granular pigment. Other tubules were dilated and their epithelial lining was flattened many contained protein casts. There was a striking thickening of the pericapsular and peritubular ${ }^{\circ}$ basement membranes, mainly consisting of PAS positive and hyaline material with a few fibroblasts and collagen fibres. The interstitial tissue was slightlyo oedematous and contained chronic inflammatory cells and an increased quantity of connective tissuez fibres. The arteries showed muscular hyperplasia and hyaline arteriosclerosis. Deposits of urate crystals were not found.

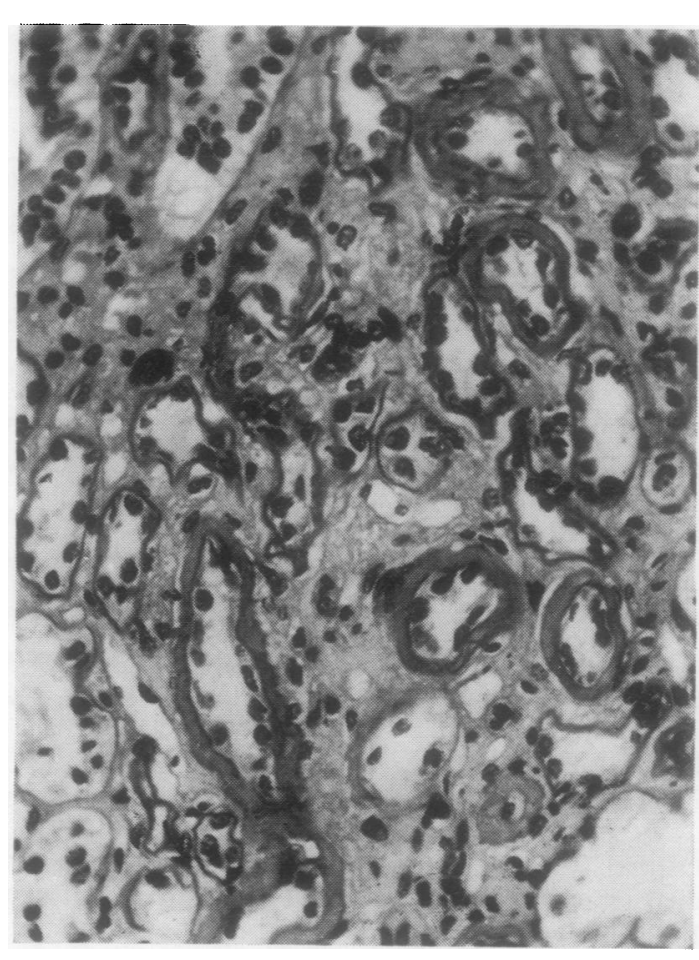

Fig. 2. Patient IV, 27, renal biopsy, PAS: tubular atrophy, thickening of peritubular basement membranes, interstitial oedema. 


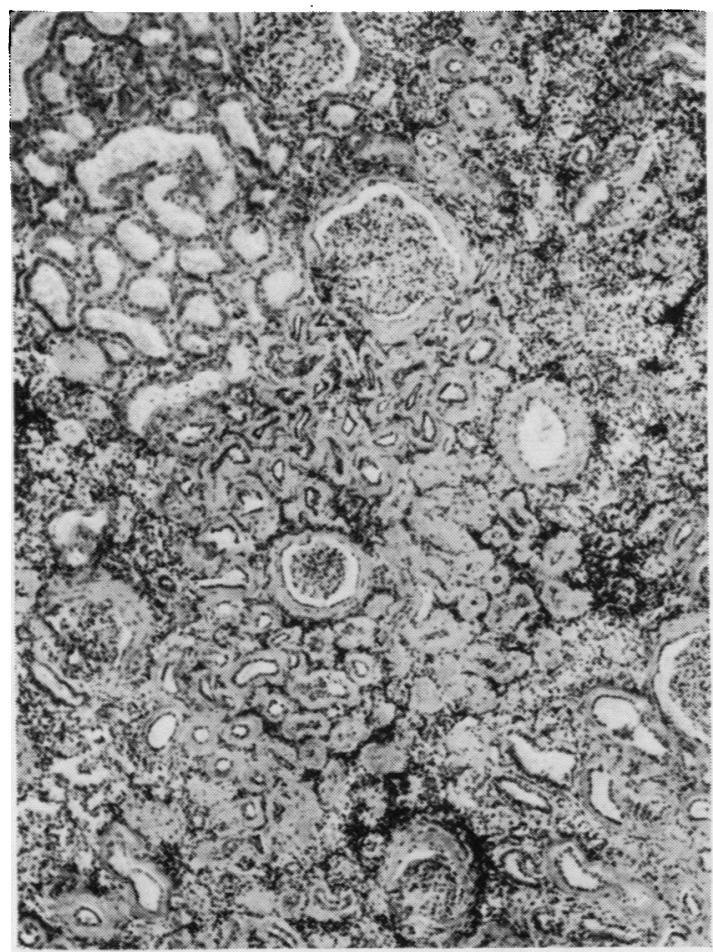

Fig. 3. Patient III, 25, necropsy, $H$ and $E$ : tubular atrophy, thickening of peritubular basement membranes and pericapsular fibrosis, interstitial infiltration with chronic inflammatory cells.

The necropsy on this patient revealed kidneys weighing 120 and $127 \mathrm{~g}$; the calyces were widened and contained some small concrements. Microscopically the main impression was that of an atrophic kidney, with sparsely interspersed hypertrophic glomeruli and tubules (Fig. 3). Many glomeruli were surrounded by an extra- or intracapsular ring of fibrous tissue; some showed more or less advanced glomerulosclerosis. Many tubules contained protein casts; the groups of atrophic tubules were surrounded by strikingly thickened basement membrane and densely fibrous interstitial tissue. Elsewhere the interstitium was heavily infiltrated with chronic inflammatory cells.

Other important features seen at necropsy were a hyperplastic parathyroid gland, weighing $660 \mathrm{mg}$, and a creamy mass in the acromioclavicular joints. This mass consisted mainly of calcium carbonate, with a small amount of uric acid. Tophi were not found. The heart was of normal weight, with slight atherosclerosis of the coronary arteries.

\section{Discussion}

The fact that 17 members of the family were or had been suffering either from gout, renal disease, or hypertension makes it probable that a familial syndrome was indeed present. In six of them the three symptoms occurred together: in most of the others two abnormalities were present. This syndrome occurred in every generation. If a child suffered from the disorder, at least one of the parents was also affected. If both parents were free from symptoms none of the children was affected. This pattern is most likely to be due to an autosomal dominant gene.

Such predominance of fatal renal disease in a gout family is very unusual and to our knowledge has been reported only once (Duncan and Dixon, 1960). As can be seen in Tables I and II, all the six patients suffering from gout had also renal disease. In six other patients renal disease was present without manifestations of gout. This raises the question whether the renal disease was the primary event which might have caused secondary gout.

The urinary uric acid excretion was found to be either normal or low (Table III). Although in patients with renal impairment a greater proportion of uric acid is disposed by extrarenal routes (Sorensen, 1962), these figures do not suggest that our patients' uric acid was produced in significantly excessive amounts. According to Sorensen (1962), about $40 \%$ (or $200 \mathrm{mg}$ per day) of the uric acid normally excreted in the urine leaves the body by intestinal uricolysis. This amount is proportionately greater with higher serum concentrations. If this were taken into account in our patients, total production would not exceed the upper limits, which are given as 700 to $900 \mathrm{mg}$ per day.

In our introduction we referred to the fact that gout is considered to be infrequent in primary renal disease, but on this point opinions differ greatly. Richet, Ardaillou, Montera, Slama, and Bougault (1961) reported 17 cases of gout in 1,600 unselected patients predominantly with renal disease. Among these 17 patients were some with amyloid. Sarre and Mertz (1965) found only two cases that were considered to have secondary gout out of 342 patients with renal disease and nitrogen retention. Talbott and Terplan (1960) are of the opinion that the evidence in favour of secondary gout is inconclusive, whereas convincing evidence of renal insufficiency as a complication of gout 'questions the supposition that any acute articular distress in a patient with increased uric acid concentration in the blood be due to renal disease'. Wijngaarden (in Stanbury et al, 1966) also favours the view that all renal disease in cases of gout may be secondary.

Descriptions in the literature of the renal lesion 
in gout are not identical. Talbott and Terplan (1960) consider pyelonephritis or at least interstitial infiltrates to be the most important lesion, and urate deposits the most characteristic feature. However, in a few patients they noted a variety of renal abnormalities, including benign and malignant arteriosclerosis and amyloid deposition, which they regarded as secondary features. They also found a definite correlation between the clinical severity of the arthritis and the renal lesions, but again with notable exceptions. Richet et al (1961) noticed frequent signs of pyelonephritis secondary to uric acid lithiasis, but found no argument for a glomerular lesion.

Authors studying the earlier stages of the disease by biopsy arrived at different conclusions. Barlow and Beilin (1968) stressed the occurrence of vascular sclerosis and Gonick et al (1965) found degeneration of cells of Henle's loops, together with fibrillar thickening of the glomerular basement membrane and vascular sclerosis, which they regard as specific and preceding functional impairment, a view not shared by others (Heptinstall, 1966; Barlow and Bellin, 1968). Greenbaum, Ross, and Steinberg (1961) and Louyot and Gaucher (1961), in biopsy studies of patients with gout, reported a variety of 'degenerative' lesions, including vascular sclerosis, glomerular hyalinization, tubular atrophy, and interstitial fibrosis. Uric acid deposits were found only occasionally. Zollinger (1966) and Heptinstall (1966) found no convincing evidence of a specific renal lesion resulting from gout. In addition, Heptinstall (1966) cites a patient in whom gout unquestionably arose after longstanding renal disease. $\mathrm{He}$ also regards the presence of uric acid crystals as the only specific sign. Even this has been challenged, however, since Verger, Leroux-Robert, Ganter, and Richet (1967) not infrequently demonstrated typical tophi with surrounding necrosis in kidneys from patients with primary renal diseases.

It is clear that the picture in all the patients we examined differs markedly from the above descriptions. The absence of uric acid deposits, even in the necropsy material, casts some doubt on the diagnosis of 'gout kidney'. Chronic lead poisoning is also a condition in which nephropathy and gout occur together. The renal lesion, apart from the intranuclear inclusions, is considered equally nonspecific. One description (Morgan, Marshall, Hartley, and Miller, 1966) also mentions the occurrence of peritubular basement membrane thickening. In this condition the uric acid clearance values are relatively more diminished in relation to the glomerular filtration rate than in other types of renal disease, and the gout may well be secondary to the renal lesion.

The thickening of the tubular basement membrane presents an unusual feature. In itself it is not a specific sign. It has been described as a prominento feature in some inherited chronic degenerative $\Rightarrow$ disorders of unknown aetiology, eg, juvenile nephro $\stackrel{-5}{\rightarrow}$ nopthisis (Ivemark, Ljungqvist, and Barty, 1960), the kidney disease associated with retinitis pigmentosa $\frac{\bar{\sigma}}{\bar{D}}$ (Meier and Hess, 1965), and renal ischaemia from? arterial occlusion (Barajas, Lupu, Kaufman, Latta, $\varrho$ and Maxwell, 1967), and in the so-called phenacetine kidney ${ }^{1}$.

In conclusion, we assume that our patients suffered from a hereditary disorder which caused $\vec{\omega}$ kidney damage, hypertension, and hyperuricaemia? and differs clinically and pathologically from thato seen in classical gout. It may therefore constitute $\mathrm{a}_{+}^{\mathrm{N}}$ separate entity. The possibility that the renal disease + is not a direct consequence of the hyperuricaemiacs should be seriously considered.

${ }^{1} \mathrm{Dr}$ R. H. Heptinstall, who reviewed the slide, has noticed a picture similar to that in our patients in diabetes and in multiple myeloma, diseases from which our patients did not sulfer.

We are grateful to Professor L. A. Hulst for permission to study his patients and for his encouragement.

Requests for reprints should be addressed to Dr E. J. Dorhout Mees, Department of Nephrology, University Hospital, Utrecht, The Netherlands.

\section{References}

Barajas, L., Lupu, A. N., Kaufman, J. J., Latta, H., and Maxwellర M. H. (1967). The value of the renal biopsy in unilateral renovascular hypertension. Nephron, 4, 231-247.

Barlow, K. A., and Beilin, L. J. (1968). Renal disease in primary gout. Quart. J. Med., 37, 79-96.

Caraway, W. T. (1955). Determination of uric acid in serum by a carbonate method. Amer. J. clin. Path., 25, 840-845.

Duncan, H., and Dixon, A. S. J. (1960). Gout, familial hyperuricaemia and renal disease. Quart. J. Med., 29, 127-135.

Gonick, H. C., Rubini, M. E., Gleason, I. O., and Sommers, S. C.O (1965). The renal lesion in gout. Ann. intern. Med., 62, 667-674.

Greenbaum, D., Ross, J. H., and Steinberg, V. L. (1961). Renal biopsy I in gout. Brit. med. J., 1, 1502-1504.

Gutman, A. B., and T'sai Fan Yü. (1957). Renal function in gout. With a commentary on the renal regulation of urate excretion $N$ and the role of the kidney in the pathogenesis of gout. Amer 0 J. Med., 23, 600-622.

Heptinstall, R. H. (1966). Pathology of the Kidney. Little Brown. Boston.

Ivemark, B. I., Ljungqvist, A., and Barry A, (1960). Juvenile nephro. nophthisis. Part 2. A histologic and microangiographic study Acta Paed., 49, 480-487.

Louyot, P., and Gaucher, A. (1961). Le rein du goutteux. Conclusions therapeutiques. Rev. méd. franç., 42, 275-280.

Merrill, J. P. (1955). The Treatment of Renal Failure. Grune and Stratton, New York.

Meier, D. A., and Hess, J. W. (1965). Familial nephropathy with retinitis pigmentosa. Amer. J. Med., 39, 58-69.

Morgan. J. M., Hartley, M. W., and Miller, R. E. (1966). Nephropathy in chronic lead poisoning. Arch. intern. Med., 118, 17-29.

Richet, G.. Ardaillou, R., Montera, H. de, Slama, R., and Bougault, T. Q (1961). Le rein goutteux. Etude de 31 cas de néphropathie $\sigma$ associée à la goutte. Presse méd. .69, 644-647. 
Richet, G., Mignon, F., and Ardaillou, R. (1965). Goutte sécondaire des néphropathies chroniques. Presse méd., 73, 633-638.

Sarre, H., and Mertz, D. P. (1965). Sekundäre Gicht bei Niereninsuffizienz. Klin. Wschr., 43, 1134-1140.

Sokoloff, L. (1957). The pathology of gout. Metabolism, 6, 230-243.

Sorensen, L. B. (1962). The pathogenesis of gout. Arch. intern. Med., $109,379-390$

Stanbury, J. B., Wijngaarden, J. B., and Fredrickson, D. S. (1966). The Metabolic Basis of Inherited Disease, 2nd. ed., p. 667.
McGraw Hill, New York.

Talbott, J. H., and Terplan, K. L. (1960). The kidney in gout. Medicine (Baltimore), 39, 405-468.

Verger, D., Leroux-Robert, C., Ganter, P., and Richet, G. (1967). Les tophus goutteux de la médullaire rénale des urémiques chroniques. Étude de 17 cas découverts au cours de 62 autopsies. Nephron, 4, 356-70.

Zollinger, H. U. (1966). Niere und ableitende Harnwege. Springer, Berlin.

\section{Reports and Bulletins prepared by the Association of Clinical Biochemists}

The following reports and bulletins are published by the Association of Clinical Biochemists. They may be obtained from The Administrative Office, Association of Clinical Biochemists, 7 Warwick Court, Holborn, London, WC1R 5DP. The prices include postage, but airmail will be charged extra. Overseas readers should remit by British Postal or Money Order. If this is not possible the equivalent of $50 \mathrm{p}$ is the minimum amount that can be accepted.

\section{SCIENTIFIC REPORTS}

3 Automatic Dispensing Pipettes. An assessment of 35 commercial instruments 1967 P. M. G. BROUGHTON, A. H. GOWENLOCK, G. M. WIDDOWSON, and K. A. AHLQUIST $85 \mathrm{p}(\$ 2)$

4 An Evaluation of 5 Commercial Flame Photometers suitable for the Simultaneous Determination of Sodium and Potassium March 1970 P. M. G. BROUGHTON and J. B. DAWSON $85 p(\$ 2)$

\section{TECHNICAL BULLETINS}

9 Determination of Urea by AutoAnalyzer November

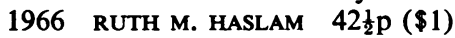

10 Filter Fluorimeters. A comparative list of 14 instruments March 1967 HANNELORE BRAUNSBERG (Reissued in response to demand. Text still valuable, list now out of date) $42 \frac{1}{2} p(\$ 1)$

11 Determination of Serum Albumin by AutoAnalyzer using Bromocresol Green October 1967 B. E. NORTHAM and G. M. WIDDOwSON $42 \frac{1}{2} p(\$ 1)$

13 An Assessment of the Technicon Type II Sampler Unit March 1968 B. C. GRAY AND G. K. MCGOWAN $42 \frac{1}{2} p(\$ 1)$
14 Atomic Absorption Spectroscopy. An outline of its principles and a guide to the selection of instruments May 1968 J. B. DAWSON and P. M. G. BROUGHTON $42 \frac{1}{2} p(\$ 1)$

15 A Guide to Automatic Pipettes (2nd edition) June 1968 P. M. G. BROUGHTON $42 \frac{1}{2} p(\$ 1)$

16 A Guide to Automation in Clinical Chemistry May

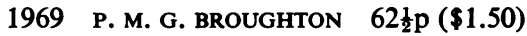

17 Flame Photometers (2nd edition) 1969 P. WILDING $62 \frac{1}{2} \mathrm{p}(\$ 1.50)$

18 Control Solutions for Clinical Biochemistry (4th edition) March 1970 P. M. G. BROUGHTON $62 \frac{1}{2} p$ $(\$ 1.50)$

19 Spectrophotometers. A comparative list of low-priced instruments readily available in Britain May 1970 C. E. WILDE and P. SEWELL $62 \frac{1}{2} \mathrm{p}(\$ 1.50)$

20 Quantities and Units in Clinical Biochemistry June 1970 P. M. G. BROUGHTON $62 \frac{1}{2} p(\$ 1.50)$ More than 30 copies in units of 10 at $20 p$

21 Filter Fluorimeters: A comparative list of 18 instruments September 1970 H. BRAUNSBERG and $s$. S. BROWN $62 \frac{1}{2} \mathrm{p}(\$ 1.50)$ 